\title{
Intraspecific and Interspecific Comparison of Toxicity of Ladybirds (Coleoptera: Coccinellidae) With Contrasting Colouration
}

Muhammad Aslam

University of South Bohemia

Oldřich Nedvěd ( $\nabla$ nedved@prf.jcu.cz)

University of South Bohemia

\section{Research Article}

Keywords: ladybug, reflex bleeding, harmonine, methoxypyrazine, succinea, melanism, polymorphism, defence

Posted Date: February 4th, 2022

DOl: https://doi.org/10.21203/rs.3.rs-1243878/v1

License: (c) (i) This work is licensed under a Creative Commons Attribution 4.0 International License. Read Full License 


\section{Abstract}

Ladybirds (Coccinellidae) use toxic compounds, mostly alkaloids in their haemolymph, for defence against predators and other enemies. The toxicity of ladybirds to predators cannot be directly assessed because predators show avoidance reactions without ingesting the beetles. The alkaloid of ladybird Harmonia axyridis showed wide range toxicity to diverse non-target organisms. Thus, we used a quick, inexpensive and easy-to-perform method using bioassays on water flea Daphnia magna for comparative quantification of the toxicity $\left(\mathrm{LD}_{50}\right)$ of whole body extracts from several species of ladybirds that differ in their warning colouration. Alien invasive aposematic polymorphic ladybird $H$. axyridis was more toxic than all the other species examined: aposematic Adalia bipunctata > cryptic Cynegetis impunctata > aposematic Coccinella septempunctata > slightly aposematic Calvia quatuordecimguttata. Three months old adults of $H$. axyridis were 3.8 times more toxic than two weeks and one month old adults. The two most common colour morphs (non-melanic novemdecimsignata and melanic spectabilis) did not differ in their toxicity.

\section{Introduction}

Chemical compounds play various roles in the ecology of ladybirds (Coleoptera: Coccinellidae), involving searching and consuming food, recognizing mates and competitors, aggregating and protection against natural enemies [1]. Adult ladybirds produce a droplet of malodourous and distasteful haemolymph from the tibio-femoral joints in a process known as reflex bleeding, which functions as both mechanical (sticky) and chemical protection [2]. Protective chemical substances include mainly alkaloids (bitter taste, potentially toxic [3] [4] and pyrazines (smelly but non-toxic, [5]).

Many predators find the defensive chemicals of ladybirds distasteful or toxic [6] [7]. The varying degree of response and toxic effects on the predators are due to the differences in the alkaloid identity specific for ladybird genera [8] and in their age [9]. Coccinella septempunctata caused toxic effects and resulted in severe liver damage in the nestlings of blue tits Cyanistes caeruleus [6]. Other studies of bird-ladybird interactions showed strong repellence effect precluding feeding the beetles and thus manifestation of their real toxicity (by tits Parus major, domestic chicks) or no effect after ingestion (in sparrow Passer montanus [10]). Ladybird reflex blood has been also found distasteful to ants [7, 11, 12]. Ladybirds are sometimes preyed on by spiders, particularly web-building spiders [13]. Nonetheless, even if trapped in the spider web, ladybirds may not be consumed due to the presence of their defensive chemicals [14].

There are also findings about toxicity of ladybirds to non-predatory, non-target organisms, including pathogenic microorganisms. The research group of Andreas Vilcinskas found that toxicity of the alkaloid harmonine of Harmonia axyridis displayed antimicrobial activity against Mycobacterium tuberculosis and Plasmodium falciparum [15]. Haemolymph of $H$. axyridis suppressed multiplication of Escherichia coli [16]. Germination of seeds and growth of root of seedlings of Sinapis alba were inhibited by extracts from $H$. axyridis [9]. 
The first use of a standard toxicity assay using cladoceran Daphnia magna [17] for quantification of ladybird chemical defence [18] revealed that $H$. axyridis was more toxic than $C$. septempunctata and Adalia bipunctata. Usefulness of this test was later confirmed by Arenas et al. [19], who report toxicity of several native British species of ladybirds to Daphnia pulex, ordered approximately according to the strength of their warning colouration: Halyzia sedecimguttata $>$ A. bipunctata $>$ Exochomus quadripustulatus $>$ Propylea quatuordecimpunctata $>$ Aphidecta obliterata $>$ Control. The water flea $D$. magna is an important crustacean species inhabiting aquatic ecosystem having Holarctic distribution. Different aspects of its ecology, life history, genetics and reactions to changes in environment and to toxic effects of chemicals are extensively studied [20]. Daphnia magna is used in aquatic toxicology [21] primarily for its ease of culture, its high sensitivity to toxins and its clonal method of reproduction [22]. The usual temperature at which toxicity tests for water fleas are performed is about $20^{\circ} \mathrm{C}$, because it does not vary much from room temperature [22].

Ladybirds are famous for their colour patterns, which are mostly aposematic, warning about their unpalatability or distastefulness [23]. Insectivorous birds exhibit avoiding behaviour against ladybirds species with diverse colour pattern [24], including immature stages [10,25]. Many ladybird species include several distinct colour forms. Birds moderately distinguished between diverse colours and patterns of polymorphic $H$. axyridis (spotted individuals better protected than unspotted [26], melanic spectabilis more often attacked than non-melanic novemdecimsignata [27]. Arenas et al. [19] did not find difference in toxicity of two different forms of A. bipunctata. Sakaki and Nedvěd [9] found only minor differences in phytotoxicity among 13 colour morphs of $H$. axyridis.

Toxicity of ladybirds usually increases with the age. Extracts from one week old adults of $H$. axyridis caused suppression of root growth of seedlings of white mustard to one third, extracts from three months old ladybirds decreased the root length to one tenth [9]. The killing efficiency of the haemolymph of $H$. axyridis against Escherichia coli increased from larval stages through the prepupal stage and during the entire period of adult life [16].

Harmonia axyridis is an ideal model for studying warning signals and toxicity of ladybirds. It is a large and highly toxic ladybird [18] found in many colour forms [28] induced genetically [29] or environmentally [30]. The alkaloids of $H$. axyridis, harmonine, like those of the other ladybirds, provide protection against a number of invertebrate and vertebrate predators suggesting its strong chemical defences [31]. It is a very successful alien invasive species with many superior properties, including chemical defence [32].

Because it is impossible to measure the direct acute toxicity of ladybirds to their predators, as they show various avoidance reactions without eating the beetles (see above), and because of the broad spectrum of organisms in which the defensive compounds of ladybirds appeared toxic, we decided to employ a simple standard test of the toxicity of whole body extracts from several species and morphs of ladybirds with different warning colouration for the water flea, D. magna. We expected that i) young ladybirds would be less toxic than older ones; ii) more aposematic (red and black) species would be more toxic 
than less aposematic and cryptic ones; iii) colour morphs of a polymorphic ladybird species would not differ in effects of their defensive chemicals.

Table 1

Lethal effects of extracts from several species and morphs of ladybirds on water flea Daphnia magna. Haxy: Harmonia axyridis, spec: $f$. spectabilis, others $\mathrm{f}$.

novemdecimsignata; $2 \mathrm{w}$ : two weeks old adults, $4 \mathrm{w}$ : 4 weeks, $3 \mathrm{~m}: 3$ months, A2P: Adalia bipunctata, CIMP: Cynegetis impunctata, C7P: Coccinella septempunctata, C14G: Calvia quatuordecimguttata. BM: average fresh body mass (mg); Control: survival percentage of D. magna in water without extract after 24 hour exposure related to specific experimental group; R: regression coefficient of the logistic equation $Y=\exp \left(b *\left(x-C_{50}\right)\right) /(1+\exp (b *(x-$ $\left.C_{50}\right)$ )) describing the effect of extract dose on survival; $b$ : regression parameter describing the slope of decrease of survival $\pm \mathrm{SE} ; \mathrm{C}_{50}$ : concentrations $(\mathrm{mg} / \mathrm{ml})$ killing $50 \%$ of $D$. magna \pm SE.

\begin{tabular}{|lllllll|}
\hline Group & BM & Control & R & b $\pm S E$ & C $_{50} \pm$ SE & \\
\hline Haxy 3m & 36.8 & 96 & 0.697 & $-23.1 \pm 6.7$ & $0.0595 \pm 0.0086$ & A \\
\hline Haxy spec & 35.7 & 96 & 0.766 & $-25.3 \pm 6.3$ & $0.0742 \pm 0.0082$ & A \\
\hline Haxy 2W & 34.6 & 80 & 0.821 & $-29.0 \pm 12.9$ & $0.221 \pm 0.014$ & B \\
\hline Haxy 4w & 34.5 & 80 & 0.941 & $-99.5 \pm 43.9$ & $0.233 \pm 0.008$ & B \\
\hline A2P & 9.7 & 86 & 0.888 & $-25.6 \pm 5.9$ & $0.270 \pm 0.010$ & C \\
\hline CIMP & 5.7 & 84 & 0.868 & $-8.7 \pm 2.3$ & $0.464 \pm 0.037$ & D \\
\hline C7P & 43.9 & 81 & 0.815 & $-3.92 \pm 1.06$ & $0.863 \pm 0.079$ & E \\
\hline C14G & 19.1 & 90 & 0.868 & $-2.45 \pm 0.45$ & $1.232 \pm 0.098$ & F \\
\hline Letters indicate significant differences in $C_{50}$ according to GLM Analysis of covariance. \\
\hline
\end{tabular}

\section{Results}

Effect of all eight groups of ladybirds (species, colour morphs, age cohorts) on survival of water flea was highly significant in the GLM model $\left(\right.$ Wald $\left._{7}=122, \mathrm{p}<10^{-6}\right)$. We found no difference between 2 weeks and 4 weeks old adults of $H$. axyridis but the toxicity of 3 months old adults was 3.8 times higher (Tab.1, Fig. 1). We found non-significant difference between melanic and non-melanic morphs of $H$. axyridis. All other species examined were less toxic than $H$. axyridis. A. bipunctata was about $1.2 \times$ and $C$. septempunctata about $3.8 \times$ less toxic to $D$. magna than young $H$. axyridis. The cryptic Cynegetis impunctata was moderately toxic ( $2 \times$ less than young $H$. axyridis) and the slightly aposematic Calvia quatuordecimguttata were least toxic (5.4× less than young $H$. axyridis, Fig. 2).

\section{Discussion}


Our study confirms previous findings $[18,19]$ that whole body extracts containing the defensive chemicals of ladybirds such as alkaloids may be lethal for the water flea $D$. magna and thus this standard toxicological assay can be used for comparative quantification of ladybird toxicity.

\section{Toxicity and invasive success}

We found that $H$. axyridis was more toxic to $D$. magna than the other ladybirds. This finding is similar to our previous results [18] where the lethal concentration $\left(C_{50}=0.06 \mathrm{mg} / \mathrm{ml}\right)$ was many times lower than that of other two conspicuous aposematic ladybirds A. bipunctata $(0.6 \mathrm{mg} / \mathrm{ml})$ and C. septempunctata (4 $\mathrm{mg} / \mathrm{ml}$ ). Our present results confirms the order of species in toxicity levels measured in the previous study, but not the magnitude of the interspecific differences. Age can be responsible for the differences (see below). It is believed that the high toxicity is one of the factors that can help the invasive alien species $H$. axyridis to be so successful in establishing in new areas [32].

Several studies have been conducted to characterize the ecological aspects, properties and biological functions of harmonine, the alkaloid of $\mathrm{H}$. axyridis. Ants Myrmica rubra showed deterrence to harmonine at concentrations of $10^{-4} \mathrm{M}$ revealing the protective function of harmonine against invertebrate predators [33]. In our related study [12] we found only small differences between six species of ladybirds in repellence to ant Lasius niger. A recent study explored the presence of parasitic microsporidia in the haemolymph of $H$. axyridis [34]. Although detrimental to other coccinellid species, these microsporidia do not affect $H$. axyridis [35] and thus harmonine protects $H$. axyridis from self-infection [36].

\section{Aposematism and toxicity: interspecific comparison}

We consider the brown-and-white $C$. quatuordecimguttata as moderately aposematic, while it was the least toxic ladybird among our species. Another study using bioassays on $D$. pulex with ladybird toxins extracts [19] included somewhat similar (orange-and-white) $H$. sedecimguttata which was the most toxic among their ladybird species analysed. Thus, toxicity of ladybirds with such type of pattern is quite unpredictable.

The cryptic ladybird $C$. impunctata that could be assumed less chemically defended against predators than the aposematically coloured species was in fact moderately toxic to water fleas in our study. In the study by Arenas et al. [19], the non-aposematic Aphidecta obliterata was the least toxic among the species used. Thus, cryptic species seem to show little to moderate toxicity.

In our study, aposematic A. bipunctata appeared to be more toxic than other species except $H$. axyridis, and it was also the second most toxic species in the study by Arenas et al. [19]. They considered both melanic and typical morphs of this species very aposematic (according to contrast and colour saturation). In our study, A. bipunctata was more toxic than C. septempunctata, while Arenas et al. [19] did not study the latter species. Repellence by A. bipunctata for ants (expressed as concentration repelling half of individuals, $C_{50}$ ) was also higher [12]. These findings are in contrast to the toxicity of the two species for the blue tit $C$. caeruleus where only $C$. septempunctata killed the nestlings [6]. It indicates 
lower efficacy of chemical protection in A. bipunctata against vertebrate predators, despite the presence of a higher concentration of alkaloids than in C. septempunctata [37]. Thus, the standard toxicity test using Daphnia species need not show accurate differences between toxicity of ladybird species against bird predators.

The hypothesized positive relationship between the aposematism and toxicity in ladybirds (called signal honesty [19]) was not supported in our study. More species of ladybirds is needed in future studies to support or falsify possible hypotheses about the role of colouration, body size, food specificity and habitat preference on their toxicity level.

The invasive $H$. axyridis, apparently as much aposematic as $A$. bipunctata and $C$. septempunctata, was the most toxic in our study. The order of repellence to ants was different: $A$. bipunctata $>H$. axyridis $>C$. septempunctata [12]. It is notable that dead individuals of $C$. septempunctata were less scavenged by invertebrates (more repellent) than otherwise highly toxic $H$. axyridis [38]. Antimicrobial activity of haemolymph of $H$. axyridis against Escherichia coli was 4 times greater than that of $C$. septempunctata [39]. We conclude that toxicity of individual species of ladybirds to diverse predators differs from repellence and from antimicrobial activity, the former probably being caused by alkaloids, the second by pyrazines, the third by alkaloids and peptides.

\section{Aposematism and toxicity: intraspecific comparison}

We observed no difference between melanic (spectabilis) and non-melanic (nevemdecimsignata) morphs of $H$. axyridis, thus showing that colour morphs may not differ in effects of their defensive chemicals. It is in accordance with the study by Arenas et al. [19] in which the extracts from melanic and non-melanic forms of $A$. bipunctata showed no differences in toxic effects on D. pulex. In other study [9], we compared phytotoxicity of 13 colour morphs of the polymorphic $H$. axyridis without consistent differences. Colour morphs of $H$. axyridis collected in the field in Czechia did not differ significantly in the parasitization rate by fungus Hesperomyces virescens and infection rate by Spiroplasma [40], while in wider center-European comparison, the melanic colour forms conspicua and spectabilis were less often parasitized than nonmelanic form novemdecimsignata [41].

Fischer et al. [42] reported non-melanic $H$. axyridis with pale-orange colour possessing a higher content of harmonine than melanic individuals. Nevertheless, Sloggett [43] observed almost equal repellence to invertebrates by melanic and non-melanic $H$. axyridis mixed to food. Fischer et al. [44] observed lower production of methoxypyrazine by red individuals than other colour forms. The alkaloid level was negatively correlated with the extent of melanic pattern on the elytra of the non-melanic $H$. axyridis [45]. Revealing the importance of methoxypyrazines as warning odours for repellence and toxicity, Fischer et al. $[42,44]$ accomplished no correlation between methoxypyrazine emission and harmonine content in $H$. axyridis. This confirms the above mentioned interspecific difference between repellence and toxicity.

\section{Age and toxicity}


Although we did not find difference in toxicity between ages 2 weeks and 4 weeks, the toxicity of much older adults (3 months) was 3.8 times higher. Similarly, phytotoxicity assay [9] showed much stronger effect caused by extracts from 3 months old adults than from 1 week old ones. The carotenoid pigment uses to accumulate throughout the life of a ladybird resulting in the darkening of elytra $[23,46]$. However, there was no relationship between alkaloid content and either elytra redness or carotenoid pigment concentration in either sex of field collected $H$. axyridis [45]. Younger orange individuals had higher number of body zones with thalli of the parasitic fungus $H$. virescens than red individuals [40], but older red individuals were not protected against $H$. virescens [47]. We suggest that some inconsistency between various studies regarding the relationship between age and toxicity can be ascribed to differences between laboratory reared and field collected ladybirds, although Arenas et al. [19] report indistinguishable toxicity of bought and wild-caught individuals of A. bipunctata.

\section{Materials And Methods}

Experimental animals. Water extracts from individuals of the following species, colour forms and age cohorts of ladybirds were available in necessary large quantities for the experiment:

1. Haxy 2w: Harmonia axyridis Pallas f. novemdecimsignata (otherwise often called succinea), two weeks old adults from laboratory stock, fed with aphids Acythosiphom pisum;

2. Haxy 4w: Harmonia axyridis f. novemdecimsignata, four weeks old adults from laboratory;

3. Haxy 3m: Harmonia axyridis f. novemdecimsignata, three months old adults from laboratory;

4. Haxy spec: Harmonia axyridis $\mathrm{f}$. spectabilis, three months old adults from laboratory;

5. A2P: Adalia bipunctata (Linnaeus) f. typica, one month old adults from laboratory;

6. C14G: Calvia quatuordecimguttata (Linnaeus), overwintering adults from native population, frozen at $-20^{\circ} \mathrm{C}$;

7. C7P: Coccinella septempunctata Linnaeus, overwintering adults from native population, frozen at $20^{\circ} \mathrm{C}$;

8. CIMP: Cynegetis impunctata (Linnaeus), 4th instar larvae from native population.

Native populations originated nearby České Budějovice, Czechia.

Adult females of water flea Daphnia magna were collected from a local pond in České Budějovice (Czechia, $49^{\circ} 00^{\prime} \mathrm{N}, 14^{\circ} 26^{\prime} \mathrm{E}$ ) during June 2019 and were maintained in the laboratory at $20^{\circ} \mathrm{C}, 16 \mathrm{~h} \mathrm{L:8h} \mathrm{D}$ photoperiod. We added tap water that was allowed to reach the gas equilibrium, i.e. loose traces of chlorine and dissolve oxygen. Only non-pregnant females with high swimming activity were used for the assay.

Extraction. Body mass of each beetle and 4th instar larva was measured on balances with $0.1 \mathrm{mg}$ precision. Each individual was homogenized in $500 \mu \mathrm{l}$ of water by crushing them with a polypropylene piston and mixing them in an Eppendorf tube. After vortexing, the mixture was centrifuged at 20000 RPM for 2 minutes, and supernatant separated. The pellet was extracted once more with the same volume of water. The merged two supernatants formed the unit experimental solution. 
Toxicity assay. We used $50 \mathrm{ml}$ plastic cups containing $20 \mathrm{ml}$ of water and 10 water fleas. To evaluate the toxicity of ladybird extracts, diverse volumes of the unit experimental solution was added to the cup to make a binary log series of concentrations. Cups containing only $20 \mathrm{ml}$ pure water with 10 water fleas were used as control. Each concentration (volume) was replicated five times. The cups were kept at $20^{\circ} \mathrm{C}$, $16 \mathrm{~h} \mathrm{~L}: 8 \mathrm{~h} \mathrm{D}$ and high air humidity to reduce evaporation of water from the cups. The number of immobilized water fleas was recorded after $24 \mathrm{~h}$ exposure. Water fleas unable to swim for 15 seconds after gentle stirring were considered immobilized/dead [21].

These methods were carried out in accordance with relevant guidelines and regulations provided by Organisation for Economic Co-operation and Development. The study was carried out in compliance with the ARRIVE guidelines 1-4, 6-10.

Statistical analysis. We started with the logistic regression $y=\exp \left(a+b^{\star} x\right) /\left(1+\exp \left(a+b^{\star} x\right)\right)$ using Statistica 13 software [40]. The independent variable was $x=B M /(B M+1000) \star V / 20$, i.e. fresh body mass $(B M)$ of ladybird in $\mathrm{mg}$ divided by $\mathrm{BM}+1000$ (mass of water added during extraction plus the mass of ladybird), multiplied by the volume $(\mathrm{V})$ of extract used in a replication in microliters divided by 20 (added to $20 \mathrm{ml}$ of tap water). Either survival ( 1 ) or mortality $(0)$ was coded as the response variable (y) with counts of water flea individuals of respective fate to calculate the response of water fleas to the toxins of ladybirds. The concentration lethal to $50 \%$ of individuals $\left(\mathrm{C}_{50}\right)$ can be calculated as the ratio of the two equation parameters $\mathrm{C}_{50}=-\mathrm{a} / \mathrm{b}$.

Then we used a modified function that estimates directly the $\mathrm{C}_{50}$ concentration $(\mathrm{mg} / \mathrm{ml})$ in the following form: $\mathrm{Y}=\exp \left(\mathrm{b} *\left(\mathrm{x}-\mathrm{C}_{50}\right)\right) /\left(1+\exp \left(\mathrm{b} *\left(\mathrm{x}-\mathrm{C}_{50}\right)\right)\right)$ in the Nonlinear estimation tool of this software package, because it provides calculation of standard errors (SE) of the parameters (see Tab. 1). Y states here for the survival rate Se in a group of 10 water fleas corrected by the survival rate of control Sc of the particular ladybird group (exposed to water), i.e. simplified Abbott's [49] formula: S=Se/Sc.

After Levene's test for normality, GLM tool Analysis of covariance with normal distribution and log link function provided comparisons (Wald statistics with 1 degree of freedom) of toxicity between the experimental groups. Effect of concentration was always highly significant $\left(p<10^{-6}\right)$, and the effect of groups was then transferred to letters marking their differences (Tab. 1).

\section{Declarations}

\section{Acknowledgments}

We thank Selgen company in Stupice, Czech Republic for providing seeds of Vicia faba for free. The study was supported by the grant 20-10003S provided by the Grant Agency of the Czech Republic.

\section{Author contributions}


ON invented and designed the experiments, statistically analysed the results and finished the manuscript, MA performed the experiments and wrote draft manuscript.

\section{Competing interests}

The author(s) declare no competing interests.

\section{References}

1. Petersson, J. Coccinellids and semiochemicals. In Hodek, I., van Emden, H., Honěk, A. (eds.) Ecology and Behaviour of the Ladybird Beetles (Coccinellidae), pp. 444-464. Wiley-Blackwell, London. (2012).

2. Stocks, I. Reflex bleeding (Autohemorrhage). United States Department of Agriculture and Clemson University, Clemson, SC, USA. (2008).

3. Pasteels, J. M., et al. Distribution and activities of the defensive alkaloids of the Coccinellidae. J. Insect Physiol. 19, 1771-1784 (1973).

4. Daloze, D., Braekman, J-. C. \& Pasteels, J. M. Ladybird defence alkaloids: Structural, chemotaxonomic and biosynthetic aspects (Col: Coccinellidae). Chemoecology 5/6, 173-183 (1995).

5. Moore, B. L., Brown, W. V. \& Rothschild, M. Methylalkylpyrazines in aposematic insects, their hostplants and mimics. Chemoecology 1, $43-51$ (1990).

6. Marples, N. M., Brakefield, P. M. \& Cowie, R. J. Differences between the 7-spot and 2-spot ladybird beetles (Coccinellidae) in their toxic effects on a bird predator. Ecol. Entomol. 14, 79-84 (1989).

7. Pasteels, J. M. Chemical defence, offence and alliance in ants-aphids-ladybirds relationships. Popul. Ecol. 49, 5-14 (2007). https://doi.org/10.1007/s10144-006-0023-3

8. Ceryngier, P., Roy, E. H. \& Poland, R. L. Natural enemies of ladybird beetles. In: Ecology and Behaviour of the Ladybird Beetles (Coccinellidae). Blackwell Publishing Ltd. (2012).

9. Sakaki, S. \& Nedvěd. O. in review. Toxicity of extracts from thirteen colour forms of Asian multicoloured ladybird Harmonia axyridis (Coleoptera: Coccinellidae) for seeds of Sinapis alba (Brassicaceae). Submitted to Insects.

10. Aslam, M., Veselý, P. \& Nedvěd, O. Response of passerine birds and chicks to larvae and pupae of ladybirds. Ecol. Entomol. 44, 792-799 (2019).

11. Sloggett, J. J. Interactions Between Coccinellids (Coleoptera) and Ants (Hymenoptera: Formicidae), and the Evolution of Myrmecophily in Coccinella magnifica Redtenbacher, 245 pp. Unpublished Ph.D. thesis, University of Cambridge. (1998).

12. Aslam, M. \& Nedvěd, O. in review a). Response of the ant Lasius niger (Hymenoptera: Formicidae) to extracts from ladybirds (Coleoptera: Coccinellidae). Submitted to Mymecological News.

13. Sloggett, J. J. Predation of ladybird beetles by the orb-web spider Araneus diadematus. BioControl 55, $631-638$ (2010a). 
14. Nentwig, W. The prey of web-building spiders compared with feeding experiments (Araneae: Araneidae, Linyphiidae, Pholcidae, Agelenidae). Oecologia 56, 132-139 (1983).

15. Röhrich, C. R., et al. Harmonine, a defence compound from the harlequin ladybird, inhibits mycobacterial growth and demonstrates multi-stage antimalarial activity. Biol. Lett. 8, 308-311 (2012).

16. Řeřicha, M., Dobeš, P., Hyršl, P., \& Knapp, M. Ontogeny of protein concentration, haemocyte concentration and antimicrobial activity against Escherichia coli in haemolymph of the invasive harlequin ladybird Harmonia axyridis (Coleoptera: Coccinellidae). Physiol. Entomol. 43, 51-59 (2018).

17. Guilhermino, L., Diamantino, T., Carolina Silva, M., \& Soares, A. M. V. M. Acute toxicity test with Daphnia magna: An alternative to mammals in the prescreening of chemical toxicity? Ecotoxicol. Environ. Safety 46, 357-362 (2000).

18. Nedvěd, O., Kalushkov, P., Fois, X., Ungerová, D. \& Rozsypalová, A. Harmonia axyridis: six-legged alligator or lethal fugu? IOBC/WPRS Bull. 58, 65-68 (2010).

19. Arenas, L. M., Walter, D. \& Stevens, M. Signal honesty and predation risk among a closely related group of aposematic species. Sci. Rep. 5, 11021 (2015).

20. Orsini, L., Decaestecker, E., De Meester, L., Pfrender, M. E. \& Colbourne, J. K. Genomics in the ecological arena. Biol. Lett. 7, 2-3(2011). doi: 10.1098/rsbl.2010.0629

21. OECD (Organisation for Economic Co-operation and Development) Daphnia sps. Acute immobilization test and reproduction test. In: Guidelines for the testing of the chemicals. Paris, 5-16 (1993).

22. Adema, D. M. M. Daphnia magna as a test animal in acute and chronic toxicity tests. Hydrobiologia 59, 125-134 (1978).

23. Majerus, M. E. N. Ladybirds. Harper Collins. London. 367 pp. (1994).

24. Dolenská M., Nedvěd O., Veselý P., Tesařová M. \& Fuchs, R. What constitutes optical warning signals of ladybirds (Coleoptera: Coccinellidae) towards bird predators: colour, pattern or general look? Biol. J. Linn. Soc. 98, 234-242 (2009).

25. Aslam M., Nedvěd O. \& Sam K. Attacks by predators on artificial cryptic and aposematic insect larvae. Entomol. Exp. Appl. 168, 184-190 (2020). DOI:10.1111/eea.12877

26. Průchová A., Nedvěd O., Veselý P., \& Fuchs R. Visual warning signals of the ladybird Harmonia axyridis (Pallas 1773): the avian predators' point of view. . Entomol. Exp. Appl. 151, 128-134 (2014). DOI:10.1111/eea.12176.

27. Borovička, M. The warning signalization of the colour forms of the harlequin ladybird (Harmonia axyridis) - Bc. thesis, in Czech. - 23 pp. University of South Bohemia, České Budějovice, Czech Republic. (2020).

28. Tan, C. C. Mosaic dominance in the inheritance of color patterns in the lady-bird beetle, Harmonia axyridis. Genetics 31, 195-210 (1946). 
29. Gautier, M., et al. The genomic basis of color pattern polymorphism in the harlequin ladybird. Curr. Biol. 28, 3296+ (2018).

30. Michie, L. J., Mallard, F., Majerus, M. E. N. \& Jiggins, F. M. Melanic through nature or nurture: genetic polymorphism and phenotypic plasticity in Harmonia axyridis. J. Evol. Biol. 23, 1699-1707 (2010).

31. Sloggett, J. J., et al. The chemical ecology of Harmonia axyridis. BioControl, 56, 643-661 (2011).

32. Roy H. E., et al. The harlequin ladybird, Harmonia axyridis: global perspectives on invasion history and ecology. Biol. Invasions 18, 997-1044 (2016). DOI 10.1007/s10530-016-1077-6

33. Braconnier, M. F., Braekman, J. C., \& Daloze, D. Synthesis of the racemic form of (z)-1, 17diaminooctadec-9-ene, an aliphatic diamine from Coccinellidae, determination of the absolute configuration of the (+)-naturally-occurring antipode. Bulletin des Sociétés Chimiques Belges 94, 605-613 (1985).

34. Nagel, N. Synthesis and bioactivity studies of harmonine: the defence alkaloid of the Asian lady beetle Harmonia axyridis. Doctoral dissertation, Friedrich-Schiller-Universität Jena. (2016).

35. Vilcinskas, A., Stoecker, K., Schmidtberg, H., Röhrich, C. R., \& Vogel, H. Invasive harlequin ladybird carries biological weapons against native competitors. Science 340, 862-863 (2013).

36. Vilcinskas, A., et al. Evolutionary ecology of microsporidia associated with the invasive ladybird Harmonia axyridis. Insect Sci. 22, 313-324 (2015).

37. de Jong, P. W., Holloway, G. J., Brakefield, P. M. \& de Vos, H. Chemical defence in ladybird beetles (Coccinellidae). II. Amount of reflex fluid, the alkaloid adaline and individual variation in defence in 2spot ladybirds (Adalia bipunctata). Chemoecology 2,15-19 (1991). https://doi.org/10.1007/BF01240661

38. Aslam, M. \& Nedvěd, O. in review. Scavenging rate on palatable and toxic insect cadavers during day and night. Submitted to Insects.

39. Knapp, M., Dobeš, P., Řeřicha, M., \& Hyršl, P. Puncture vs. refl ex bleeding: Haemolymph composition reveals signifi cant differences among ladybird species (Coleoptera: Coccinellidae), but not between sampling methods. Eur. J. Entomol. 115, 1-6 (2018). doi: 10.14411/eje.2018.001

40. Awad M., Piálková R., Haelewaters D., \& Nedvěd O. in review. Infection pattern of ladybird Harmonia axyridis (Coleoptera: Coccinellidae) by ectoparasitic fungus Hesperomyces virescens and endosymbiotic bacteria. submitted to J. Invertebr. Pathol.

41. Haelewaters D., Hiller T., Ceryngier P., Eschen R., Gorczak M., Houston M.L., Kisło K., Knapp M., Landeka N., Pfliegler W.P., Zach P., Aime C., \& Nedvěd O., in review: Effect of abiotic factors on the prevalence of a common parasite of the invasive alien ladybird Harmonia axyridis. submitted to Frontiers Ecol. Evol. ID: 773423

42. Fischer, C., et al. Harmonia axyridis (Pallas) secondary metabolites quantification in relation with aposematism: Part I: Harmonine quantification. In: Abstracts. HTC 11-Eleventh international symposium on hyphenated techniques in chromatography and hyphenated chromatographic analyzers \& HTSP-International symposium on hyphenated techniques for sample preparation. Catholic University College Bruges-Ostend in Bruges 25-29 (2010a). 
43. Sloggett, J. J. Colour pattern polymorphism and chemical defence in Harmonia axyridis. In: Babendreier D, Kenis M, Aebi A, Roy $\mathrm{H}$ (eds) Working group "Benefits and risks associated with exotic biological control agents" at Engelberg (Switzerland), IOBC/WPRS Bull. 58, 115-123 (2010b).

44. Fischer $\mathrm{C}$, et al. Harmonia axyridis (Pallas) secondary metabolites: quantification in relation with aposematism. Part II: pyrazine quantification. In: Abstracts. HTC 11-Eleventh international symposium on hyphenated techniques in chromatography and hyphenated chromatographic analyzers \& HTSP-International symposium on hyphenated techniques for sample preparation. Catholic University College Bruges-Ostend in Bruges 25-29 (2010b).

45. Bezzerides, A. L., McGraw, K. J., Parker, R. S., \& Husseini, J. Elytra color as a signal of chemical defense in the Asian ladybird beetle Harmonia axyridis. Behav. Ecol. Sociobiol. 61, 1401-1408 (2007).

46. Nedvěd, O., Aslam, M., Abdolahi, R., Sakaki, S., \& Soares, A. O. Age and temperature effects on accumulation of carotenoids in ladybirds. IOBC WPRS Bull. 145: 33-36 (2019).

47. Fiedler, L. \& Nedvěd, O. Fifty shades of the ladybird Harmonia axyridis and sexually transmitted disease. J. Insect Sci. 19, 10 (2019).

48. Tibco Software Inc. Statistica (data analysis software system), version 13. http://statistica.io. (2017).

49. Abbott, W. S. A method of computing the effectiveness of an insecticide. J. Econ. Entomol. 18, 265267 (1925).

\section{Figures}




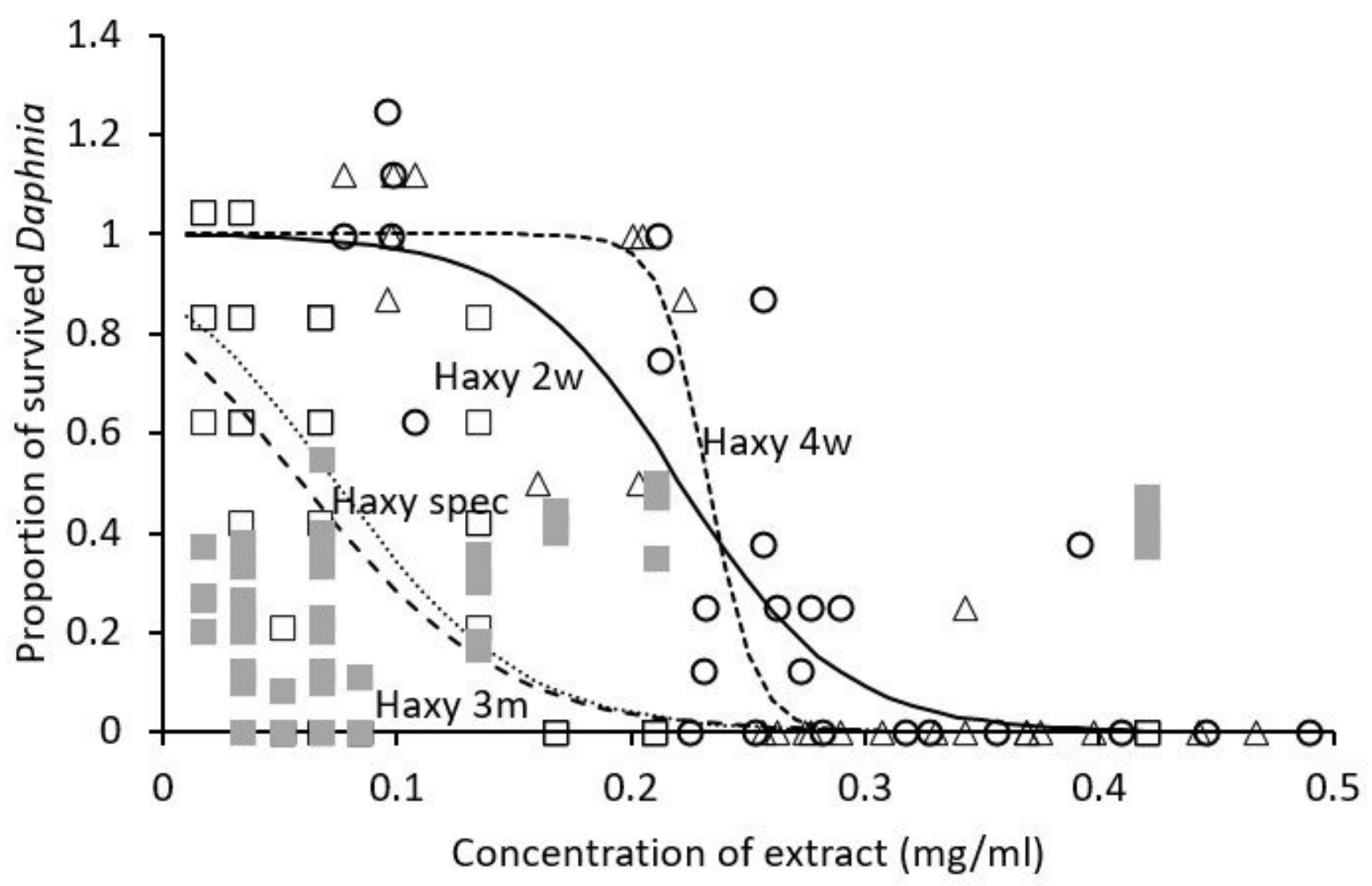

Figure 1

Effect of concentration of extract from ladybird Harmonia axyridis on survival of water flea Daphnia magna after 24 hours. Open squares and dashed line: Haxy3m f. novemdecimsignata, three months old adults; Grey squares and dotted line: Haxy spec f. spectabilis, three months old adults; Open circles and solid line: Haxy 2w f. novemdecimsignata, two weeks old adults; Open triangles and dashed line: Haxy $4 \mathrm{w}$ f. novemdecimsignata, four weeks old adults. 


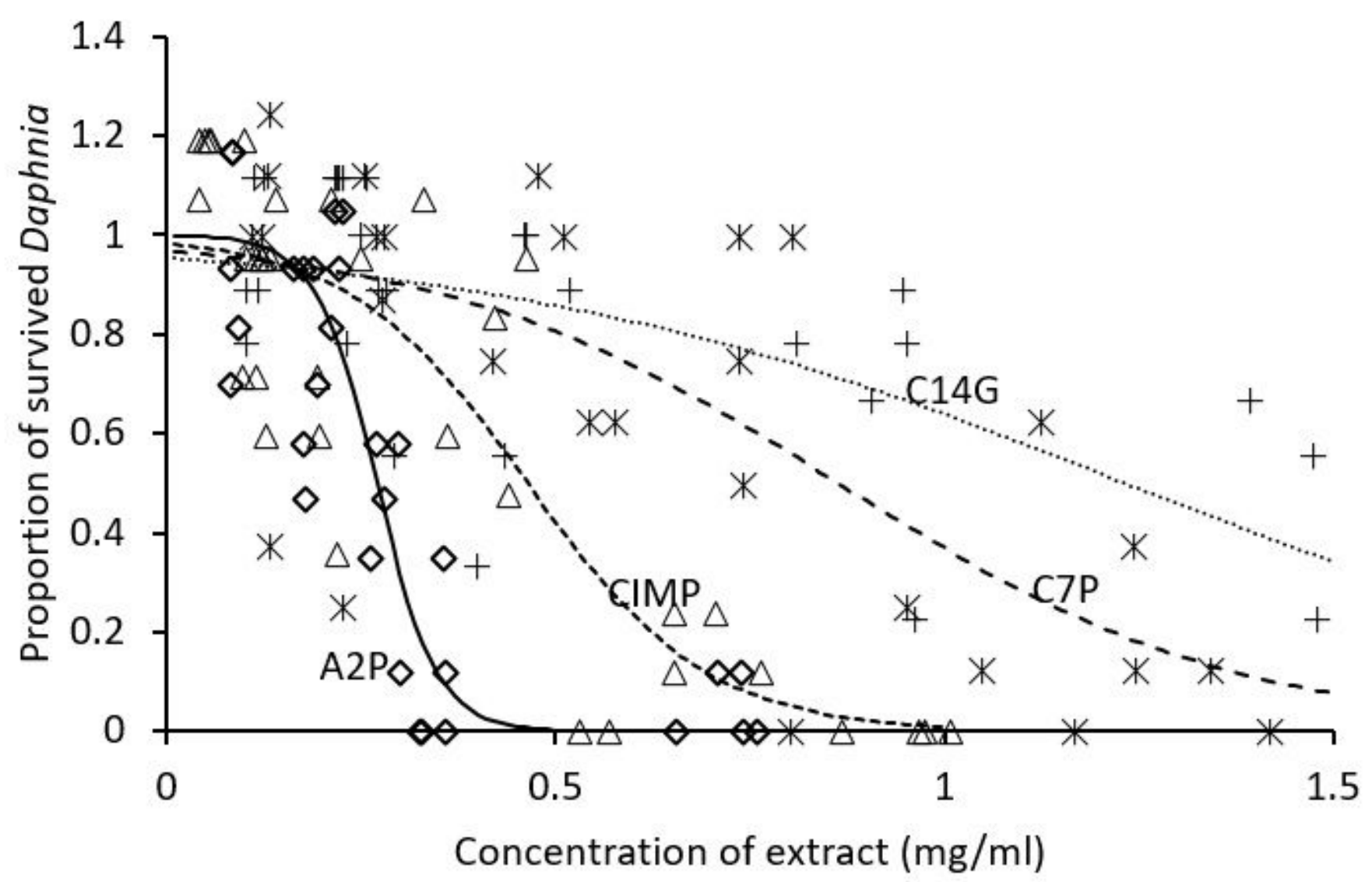

Figure 2

Effect of concentration of extract from ladybirds on survival of the water flea Daphnia magna after 24 hours. Diamonds and solid line: A2P Adalia bipunctata; Triangles and short dashed line: CIMP Cynegetis impunctata larvae; Stars and long dashed line: C7P Coccinella septempunctata; Crosses and dotted line: C14G Calvia quatuordecimguttata. 